\title{
Northern Technology and Engineering: Information Support of the Problem
}

\author{
Valentina V. Rykova* \\ State Public Scientific-Technological Library of the $S B R A S$ \\ 15 Voskhod Str., Novosibirsk, 630102, Russia
}

Received 27.07.2016, received in revised form 09.02.2017, accepted 15.02.2018

The article represents databases for research information support on the problems related to providing northern regions with reliable equipment and technologies. It gives characteristics of information resources on cold regions engineering topic from foreign and Russian databases: IEEE Xplore, ScienceDirect, ASCE Library, VINITI RAS, "Scientific Sibirica". It analyses a documentary flow "Northern engineering and technology" selected from information array "Problems of the North", which is a constituent part of DB with current replenishment "Scientific Sibirica" generated by the Department of Scientific Bibliography of the State Public Scientific-Technological Library of the Siberian Branch of the Russian Academy of Sciences. The documentometric analysis (a kind of bibliometric one) shows the chronological, quantitative, type-species, thematic structures of Russian documents.

Keywords: northern engineering, cold regions technologies, Arctic, databases, information support, documentometric analysis.

Citation: Rykova V.V. Northern technology and engineering: information support of the problem, J. Sib. Fed. Univ. Eng. technol., 2019, 12(1), 106-112. DOI: 10.17516/1999-494X-0033.

\section{Северные технологии и техника: \\ информационная обеспеченность темы}

\author{
В.В. Рыкова \\ Государственная публичная \\ научно-техническая библиотека СО РАН \\ Россия, 630102, Новосибирск, ул. Восход, 15
}

В статье представлены базы данных для информационной поддержки научных исследований по проблемам, связанным с обеспечением северных регионов с надежным оборудованием и технологиями. Дана характеристика информачионных ресурсов, касающихся проблем

(C) Siberian Federal University. All rights reserved

This work is licensed under a Creative Commons Attribution-NonCommercial 4.0 International License (CC BY-NC 4.0).

* Corresponding author E-mail address: onbryk@spsl.nsc.ru 
создания и работы техники в холодных регионах из зарубежных и российских баз данных: IEEE Xplore, ScienceDirect, ASCE library, ВИНИТИ РАН, «Научная Сибирика». Анализируется документальный поток по теме "Северные технологии и техника в северном исполнении», выделенный из информаџионного массива «Проблемы Севера», который является составной частью БД с текущим пополнением «Научной Сибирики», генерированной отделом научной библиографии Государственной публичной научно-технической библиотеки общественного Сибирского отделения Российской академии наук. Потокометрический анализ (разновидность библиометрического) отражает хронологическую, типо-видовую, тематическую структуру российского документопотока.

Ключевые слова: северные технологии, техника в северном исполнении, Арктика, базы данных, информационное сопровождение научных исследований, потокометрический анализ.

\section{Introduction}

Currently, a growing interest in the Arctic is observed, because large areas of the Far North are the most important geostrategic and resource regions. But the lack of a developed transport infrastructure and highly qualified labour resources complicates the development of this region. Under modern conditions the economic efficiency in northern regions is greatly determined by the level of technologies development and engineering designed specifically to work under severe conditions of the Arctic. Researches aimed at developing the northern technologies and equipment in the northern fulfillment need the full-value information support accounting requirements of new information technologies. Intensive development of cold regions engineering sphere is observed not only in northern countries (Norway, Canada, Russia), but also in China, Japan, USA. The importance of relevant information support of these research is obvious.

\section{Cold region engineering information support}

IEEE Xplore Digital Library provides access to the world technical literature in engineering and technology. The request "cold region engineering" shows about 1,200 documents for 19432016, mainly conferences proceedings. The most significant international forums are TENCON: IEEE Region 10 Conference; Remote Sensing, Environment and Transportation Engineering; IEEE International Symposium on Geoscience and Remote Sensing, Underwater Technology, and others [1-7].

The highest publication activity is shown by Chinese, Japanese, American, Canadian authors. Their researches are related to various techniques and tools of snow, ice, permafrost observation, new devices to operate under severe climatic conditions. Norwegian publications are devoted to marine engineering study. The Cold Region and Arid Region Environmental and Engineering Research Institute (the Chinese Academy of Sciences), National Institute of Polar Research (Japan), Cold Regions Research and Engineering Laboratory (United States) brings together groups the most productive foreign authors carrying out research in this field.

DB ScienceDirect (Elsevier) concentrating information on engineering and medicine covers $25 \%$ of world scientific publications. The request "cold region engineering" gives more than 5,000 journal articles concerning the topic for the last 2 decades (1997-2016). It should be mentioned that filters applying is needed in this DB to get relevant information. The most productive periodicals are the following: International Journal of Heat and Mass Transfer, Applied Thermal Engineering, Renewable

$$
-107-
$$


Energy, Materials Science and Engineering, Building and Environment, Cold Regions Science and Technology, Procedia Engineering, etc.

It's worth to name the periodical of the American Society of Civil Engineers "Journal of Cold Regions Engineering", which materials are presented at ASCE Library (http://ascelibrary.org/ journal/jcrgei). The whole content of this journal is devoted to American and foreign research of northern engineering and technologies. The top 5 cited work of this resource are in the references [8-12].

The research provision with systematized information on engineering and technology in Russia have traditionally solved by the All-Russian Institute of Scientific-Technical Information of the Russian Academy of Sciences (VINITI RAS), which produces abstract journals based on the bibliographic database (DB) consisting of 28 thematic fragments and 217 sections, which have enclosed materials since 1981. To support engineering studies the following sections should be noted: Automatics and Radioelectronics, Transport Mining Engineering, Corrosion and Corrosion Protection, Metallurgy, Mechanics, Welding, Electrical Engineering, Energetics, etc.

A significant limitation of using all the mentioned above information resources is availability of their full-texts only for subscribers, as well as the difficulties in searching regional materials.

The largest information array devoted to this topic in Russia is DB "Problems of the North" generated by the State Public Scientific-Technological Library of the Siberian Branch of the Russian Academy of Sciences (SPSTL SB RAS) - the central body of scientific and technical information of SB RAS. The mentioned above DB in 2011 was included in regional DB "Scientific Sibirica" covering information on the Arctic, Siberia and the Far East with its own subject heading.

The information array "Problems of the North" of DB "Scientific Sibirica" includes systematized materials on the northern technologies and engineering combined in several groups:

1) providing production with northern technology and equipments and in the northern fulfillment,

2) problems of building under northern conditions (house- and civil, industrial construction),

3) problems of deposit (ore, non-metallic, coal and hydrocarbon ones) development under northern conditions and in permafrost areas,

4) transportation development in northern regions,

5) northern agriculture problems (equipment and technology).

\section{The Russian documents flow bibliometric analysis}

The information support is not limited by DBs generation, but is also supported by a documentometric (bibliometric) research. A documentary flow (DF) on the problems of northern engineering and technologies from IM "Problems of the North" was isolated and its temporal, thematic, species-typical structures were analyzed. The volume of DF is above 11,800 documents for a 30-year period (1987-2016).

The DF temporary structure is shown in Fig. 1, it indicates the continued interest of scientists and specialists to the problem. There was some decline in publication activity in the $90 \mathrm{~s}$ of the last century due to the crisis processes that affected both Russian economy and science. It should be noted that documents edited in 2015-2016 are actively entered the library nowadays, that's why the DF amount for the last five years will be much higher. 


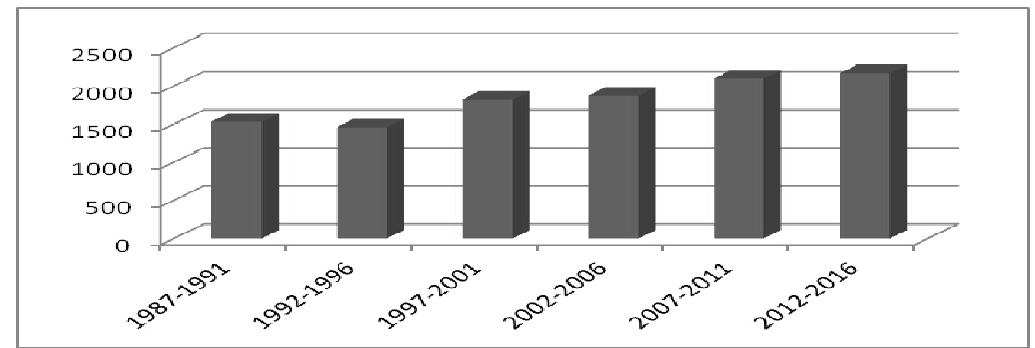

Fig. 1. DF dynamics

DF typical structure evidences that the articles from periodicals account about $40 \%$ of it. A "core group" Russian journals with high publication activity on this issue are the following "Gornyi zhurnal [Mining Journal]", "Nauka i tekhnika v gazovoi promyshlennosti [Science and technology in gas industry]", "Avtomatizatsiya i sovremennye tekhnologii [Automation and modern technologies]", "Nauka i tekhnika Yakutii [Science and Engineering in Yakutia]" and others.

Almost half (48\%) of DF documents are presented by conferences proceedings. It should be noted that scientific meetings devoted to the aforesaid problem are regularly held at various levels (from regional to international ones), many of them work on a regular basis, such as "The dynamics of systems, mechanisms and machines", "EURASTRENCOLD: symposium on the problems of materials and machines strength for cold climate regions", "History and prospects of transportation development at the Russian North", "Materials for technical devices and structures used in the Arctic", "Terrestrial transportation and technological complexes and equipment", "The Northern Sea Route: the Arctic communications development in the global economy", etc. It should be paid attention that some conference proceedings was published only in a digital form on CD-ROMs, DB has the possibility of acceding from a bibliographic description of a document to its fill text by organizing a hyperlink that allows the user to get to know the original article without visiting the library.

Monographic editions make up to $4 \%$ of DF, among them the significant part refers to thesis abstracts. This fact allows forecasting edition books on the research subjects in the near future, that will become a worthy completion of scientific studies on the issue. Entering the library theses abstracts, which PhD dissertations were defended in 2015, are presented in references [13-23].

The specialization of northern resource areas is clearly traced in the DF thematic structure. The third part of DF materials refers to technologies of deposits mining and fields exploitation in the Arctic, or mining infrastructure creation in permafrost regions. About DF $34 \%$ are devoted to transportation technical-technological problems (laying and maintaining auto roads, railways, pipelines in northern areas). The tenth part of the DF documents concentrates on improvement of technologies in building under severe climatic conditions.

An interesting fact is that the DF regional structure coincides with the geography of research institutions with the highest publication activity.

$42 \%$ of publications relate to materials on technology and engineering created for the northern regions of Siberia. Siberian scientists and specialists work actively in the following SB RAS' research centers: Institute of Physical-Technical Problems of the North (Yakutsk), Institute of Problems of the North Development (Tyumen), Institute of Chemistry and Chemical Technology (Krasnoyarsk), as 
well as teachers and researchers of higher schools - Yakutsk, Tomsk, Tyumen universities. Above one third of DF are publications of authors working in establishments of the Russian European North on creating new technologies and equipment in the Kola Scientific Center of RAS (Mining Institute, Institute of Physical-Technical Problems of the Northern Energetics) and Ukhta University (Komi republic). About a third of DF has no clear geographical frameworks, these works are devoted to the northern technologies and engineering in general.

\section{Conclusion}

In conclusion, it should be noted that information resources on northern engineering are diverse in content and edition types. The great number of information is published in scientific forum proceedings, which are held regularly on the issue, and periodicals specializing in this topic; there are journals devoted entirely to this problem. Research centers of cold regions engineering are functioning in a raw of countries. Investigations in this field of science are held actively by Russian, Chinese, Japanese, Canadian and American scientists, it is reflected in their publication activity.

Unfortunately the most part of publications' full-text in DBs is available either by subscription, or by license agreement. Free full-text information will succeed research information support of the topic.

\section{References}

[1] Birjandi A.H., Ridd S.C., Bibeau E.L. An innovative low cost hydrokinetic site selection technique for cold climateregions. OCEANS 2015: IEEE Conf., Genova, 2015, 1-4.

[2] Di Leo D., Coccia A., Meta A., Corucci L. Radiometric calibration of the SnowSAR images of sub-arctic open tundra watershed in Canada. IET Intern. Radar Conf. 2015, 2015, 1-7.

[3] Yin L., Li Ya. Research of Suitability Indicators on Ground-Source Heat Pump in Hot Summer and Cold Winter Area. Intern. Conf. on Intelligent Transportation: Big Data and Smart City (ICITBS-2015), 2015, 613-616.

[4] Kishi N., Asada A., Abukawa K., Fujisawa K. Inspection methods for underwater structures of ports and harbors. Underwater Technology 2015: IEEE conf., 2015, 1-5.

[5] Zaki R., Barabadi A. Icing and performance of offshore production facilities in cold climate region. IEEE Intern. Conf. on Industr. Eng. a. Eng. Management, 2014, 724-728.

[6] Taheri S., Farzaneh M., Fofana I. Application of dynamic two-arc model to flashover of HVDC insulators subjected to cold climate regions. Electric. Insulation a. Dielectr. Phenomena: IEEE Conf. CEIDP-2015, 2015, 205-208.

[7] Smith Z., Negnevitsky M., Wang X., Michael K. Glaciothermal power generation in cold climate regions. 2015 IEEE Power \& Energy Soc. Gen. Meet, 2015, 1-5.

[8] Simonsen E., Janoo V.C., Isacsson U. Resilient Properties of Unbound Road Materials during Seasonal Frost Conditions. J. of Cold Regions Engineering, 2002, 16 (1), 28-50.

[9] Fay L., Shi X. Laboratory Investigation of Performance and Impacts of Snow and Ice Control Chemicals for Winter Road Service. J. of Cold Regions Engineering, 2011, 25 (3), 89-114.

[10] Kong Q., Wang R., Song G., "Joey” Yang Zh., Still B. Monitoring the Soil Freeze-Thaw Process Using Piezoceramic-Based Smart Aggregate. J. of Cold Regions Engineering, 2014, 28 (2), DOI: 10.1061/(ASCE)CR.1943-5495.0000066. 
[11] Cheng G. Permafrost Studies in the Qinghai-Tibet Plateau for Road Construction. J. of Cold Regions Engineering, 2005, 19 (1), 19-29.

[12] Tuan Ch.Y. Roca Spur Bridge: The Implementation of an Innovative Deicing Technology. $J$. of Cold Regions Engineering. 2008, 22 (1), 1-15.

[13] Баянов А.Е. Теплофизическое обоснование круглогодичного кучного выщелачивания золотосодержащих руд в условиях низких температур (на примере Савкинского месторождения): автореф. дис. ... канд. техн. наук. Чита, 2015. 18 с. [Bayanov A.E. Thermalphysical substantiation of all-year-round heap leaching of gold ores at low temperatures (a case of Savkinskoe deposit): theses abstr. Chita, 2015, 18 p. (In Russian)].

[14] Григорьев А.В. Повреждение и ресурс бандажа локомотовного колеса в условиях низких климатических температур: автореф. дис. ... канд. техн. наук. Комсомольск-на-Амуое, 2015. 23 c. [Grigoriev A.V. Damage and resource of locomotive wheel brace under low climatic temperatures: thesis abstr. Komsomolsk-on-Amur, 2015, 23 p. (In Russian)].

[15] Дозморов П.С. Методы и аппаратура контроля гранулометрического состава $и$ проницаемости горных пород: автореф. дис. ... канд. техн. наук. Томск, 2015. 19 c. [Dozmorov P.S. Methods and apparatus to control particle size distribution and rocks permeability [to improve the accuracy of estimating of oil-gas fields reserves in West Siberia]: theses abstr. Tomsk, 2015, 19 p. (In Russian)].

[16] Захарова М.И. Анализ и оценка риска аварий резервуаров и газопроводов при низких температурах: автореф. дис. ... канд. техн. наук. Уфа, 2015. 25 с. [Zakharova M.I. The risk analysis and assessment of accidents in reservoirs and pipelines at low temperatures: theses abstr. Ufa, 2015, 25 p. (In Russian)].

[17] Кондрашов А.О. Обоснование технологии регулирования фильтраџионных потоков 8 низкопроницаемых нефтяных коллекторах с использованием гидрофобизированного полимерного состава: автореф. дис. ... канд. техн. наук. СПб., 2015. 20 с. [Kondrashov A.O. Justification of control technology of seepage flows in low-permeable oil reservoirs using hydrophobized polymer composition [for West Siberian fields]: theses abstr. St Petersburg, 2015, 20 p. (In Russian)].

[18] Кузнецов Д.В. Обоснование технологических комплексов горнотранспортного оборудования для открытой разработки рудных месторождений в суровых климатических условиях: автореф. дис. ... канд. техн. наук. Красноярск, 2015. 19 с. [Kuznetsov D.V. Substantiating technological complexes of mining-transport equipment for open-cast mining of ore deposits in severe climatic conditions: theses abstr. Krasnoyarsk, 2015, 19 p. (In Russian)].

[19] Лалаев К.Д. Интенсификаиия производства и транспортировки углеводородного сырья в северных районах Западной Сибири: автореф. дис. ... канд. техн. наук. Уфа, 2015. 24 с. [Lalaev K.E. Intensification of hydrocarbons production and transportation in the northern regions of Western Siberia: theses abstr. Ufa, 2015, 24 p. (In Russian)].

[20] Миннегулова Г.С. Обоснование технологии транспортирования смеси сжиженных углеводородов газоконденсатных месторождений Крайнего Севера по низкотемпературным магистральным трубопроводам: автореф. дис. ... канд. техн. наук. СПб., 2015. 20 с. [Minnegulova G.S. Substantiation of transporting liquefied mixture gas of the Far North gascondensate fields at low temperature pipelines: theses abstr. St Petersburg, 2015, 20 p. (In Russian)]. 
[21] Сидоров М.М. Влияние ультразвуковой ударной обработки на механические свойства и перераспределение остаточных напряжений сварных соединений трубопроводов, эксплуатируемых в условиях Сибири и Крайнего Севера: автореф. дис. ... канд. техн. наук. Томск, 2015. 18 c. [Sidorov M.M. Effect of ultrasonic impact treatment on mechanical properties and residual stress redistribution in welded joints of pipelines operated in Siberia and the Far North: theses abstr. Tomsk, 2015, 18 p. (In Russian)].

[22] Уварова Т.Е. Истирающее воздействие дрейфующего ледяного покрова на морские гидротехнические сооружения: автореф. дис. ... д-ра техн. наук. СПб., 2015. 32 с. [Uvarova T.Е. Abrading effects of drifting ice on marine hydraulic-engineering constructions: theses abstr. St. Petersburg, 2015, 32 p. (In Russian)].

[23] Юшин Е.С. Оченка коррозионно-усталостного состояния насосно-компрессорных труб в минерализованных средах: автореф. дис. ... канд. техн. наук. Ухта, 2015. 24 с. [Yushin E.S. Evaluation of corrosion-fatigue condition of the tubing in mineralized environments [at the Russian European North fields]: theses abstr. Ukhta, 2015, 24 p. (In Russian)]. 